\title{
A gestão do desenvolvimento local no Brasil: (des)articulação de atores, instrumentos e território*
}

\author{
Rafael D'Almeida Martins** \\ José Carlos Vaz*** \\ Eduardo de Lima Caldas****
}

SumÁrio: 1. Introdução; 2. Nota metodológica; 3. Visões de desenvolvimento local; 4. As experiências; 5 . Conclusão.

Summary: 1 . Introduction; 2. Methodological note; 3. Local development views; 4. The experiences; 5 . Conclusion.

\footnotetext{
* Artigo recebido em set. 2009 e aceito em mar. 2010. Amplia reflexões anteriores dos autores apresentadas no I Seminário Internacional sobre Desenvolvimento Local (Unesp/Rio Claro) e no I, II e III Encontro Nacional de Administração Pública e Governança da Anpad no Rio de Janeiro, São Paulo e Salvador. Diversas etapas da pesquisa foram realizadas com apoio da Fundação Friedrich Ebert (FES) e do Instituto Pólis. Os autores agradecem a todos os pesquisadores que realizaram os estudos de caso e o trabalho de campo. Rafael D'Almeida Martins agradece apoio da Coordenação de Aperfeiçoamento de Pessoal de Nível Superior (Capes) e a hospitalidade do Departamento de Análise de Política Ambiental (EPA), Instituto de Estudos Ambientais (IVM) da Vrije Universiteit Amsterdam, Holanda.

** Doutorando em ambiente e sociedade pelo Núcleo de Estudos e Pesquisas Ambientais da Universidade Estadual de Campinas (Nepam/Unicamp). Graduado em administração pública pela Escola de Administração de Empresas de São Paulo da Fundação Getulio Vargas (Eaesp/FGV). Pesquisador visitante no Institute for Environmental Studies (IVM), Vrije Universiteit Amsterdam, Holanda. Bolsista Capes. Endereço: Rua dos Flamboyants, 155 - Cidade Universitária Zeferino Vaz _ CEP 13084-867, Campinas, SP, Brasil. E-mail: rafael@cepps.org.br.

*** Doutor em administração de empresas e mestre em administração pública e governo pela Escola de Administração de Empresas de São Paulo (Eaesp/FGV). Graduado em administração de empresas pela Faculdade de Economia, Administração e Contabilidade da Universidade de São Paulo (FEA/USP). Professor da Escola de Artes, Ciências e Humanidades da USP. Coordenador do Comitê Executivo da Rede LogoLink e membro do Conselho Diretor e Fiscal do Instituto Pólis. Endereço: Rua Arlindo Béttio, 1000 - Ermelino Matarazzo - CEP 03828-000, São Paulo, SP, Brasil.E-mail:vaz@usp.br.

**** Doutor em ciência política pela Faculdade de Filosofia, Letras e Ciências Humanas da Universidade de São Paulo (FFLCH/USP). Mestre em administração pública e governo pela Escola de Administração de Empresas de São Paulo (Eaesp/FGV) e em ciência política (FFLCH/USP). Graduado em economia pela Faculdade de Economia, Administração e Contabilidade da Universidade de São Paulo (FEA/USP). Professor da Escola de Artes, Ciências e Humanidades da Universidade de São Paulo (USP). Endereço: Rua Arlindo Béttio, 1000 - Ermelino Matarazzo — CEP 03828-000, São Paulo, SP, Brasil. E-mail: eduardocaldas@usp.br.
} 
Palavras-chave: desenvolvimento local; gestão; território; articulação de atores; instrumentos para gestão social.

KEY WORDs: local development; comparative analysis; territory; actors' articulation; instruments for social governance.

As ideias de desenvolvimento local são controversas, pouco consensuadas e, às vezes, até antagônicas entre si, tanto no Brasil quanto no debate internacional. Diante dessa polêmica, este artigo discute a gestão do desenvolvimento local a partir de instrumentos selecionados por meio de uma análise exploratória não apenas conceitual e teórica, mas sobretudo prática. Do ponto de vista metodológico, foi realizada uma análise comparada de experiências regionalmente distribuídas, levando-se em conta suas inserções em redes sociais e seus resultados econômicos na região em que está inserida (Sul, Sudeste e Nordeste). Percebe-se que refletir sobre o desenvolvimento local desdobra-se em duas frentes: uma de reprodução da lógica capitalista em escala localizada (tradicional) e outra de tentativas contra-hegemônicas (solidária). Assim, algumas questões centrais foram identificadas para orientar uma reflexão sobre a intervenção dos atores da sociedade civil e dos governos na formulação de propostas e iniciativas de desenvolvimento econômico local.

\section{Local development management in Brazil: actors' (dis)articulation,} instruments and territory

The ideas of local development are controversial, there is little consensus, and sometimes they are even antagonistic, in Brazil and abroad. Given this controversy, this article discusses local development management, based on instruments selected through an exploratory analysis, not only conceptual and theoretical, but above all practical. It presents a comparative analysis of regionally distributed experiences taking into account their insertion in social networks and the economic results in their regions (South, Southeast and Northeast). On reflecting about local development one can perceive that it unfolds in two fronts: locally, a reproduction of the capitalist logic (tradition), and counter-hegemonic attempts (solidarity). Some key issues were identified to guide a reflection on the role of civil society actors and governments in the formulation of proposals and initiatives for local economic development.

\section{Introdução}

Este artigo apresenta uma análise comparada de experiências de desenvolvimento local, analisadas por uma perspectiva socioeconômica: a experiência da Associação de Apicultores de Simplício Mendes, no Piauí; dos polos moveleiros de Votuporanga, em São Paulo e Rio Grande do Sul; a experiência do Complexo Couro Calçadista e da Cooperativa dos Citricultores Ecológicos do Vale do Caí (Ecocitrus), também do Rio Grande do Sul; os minidistritos 
industriais e de serviços de São José do Rio Preto, em São Paulo; o Consórcio Intermunicipal do Grande $\mathrm{ABC}$, no mesmo estado; o Consórcio Intermunicipal de Abastecimento (Cinpra), do Maranhão; e finalmente o Banco Palmas da cidade de Fortaleza, no Ceará.

O artigo é resultado de uma rodada de pesquisas, debates e sistematização de experiências, recaindo sobre questões que envolvem a produção, acumulação e distribuição da riqueza e da renda geradas e geridas socialmente. Vale ressaltar que a dimensão econômica, na abordagem adotada, não se sobrepõe a outras dimensões, mas está intrinsecamente vinculada às sociais, ambientais, culturais e políticas.

O "local" não foi entendido a partir de um recorte administrativo, portanto nem sempre se sobrepôs ao municipal. Em alguns casos era mais amplo e abarcava uma região inteira, em outros abarcava apenas determinados bairros de um conjunto de municípios. Assim, o local não se refere ao tamanho, mas abarca o conjunto de relações que existem em um determinado território, seja ele uma microrregião ou uma cidade, considerando as heterogeneidades e especificidades do lugar (Santos e Rodríguez-Garavito, 2006). Consideramse também os atores sociais e a institucionalidade da localidade, com sua diversidade e potencialidades econômicas, sociais, ambientais e as diferentes alternativas de atuação para a transformação e o desenvolvimento do local.

Durante a pesquisa foi observado que várias dessas experiências estavam inseridas em arranjos produtivos locais (APLs). Tal fato trouxe algumas indagações: será que para entendermos as experiências de desenvolvimento econômico local, necessariamente teremos que adentrar o debate sobre a articulação de atores em torno de clusters industriais? ${ }^{1}$ Quem são esses atores e quais os seus papéis? Ou será que esses arranjos e articulações são mais um elemento do que chamamos de experimentalismo difuso? ${ }^{2}$ Longe de encontrar respostas, este artigo procura destacar essas questões como novos e importantes elementos para análise do processo de gestão social do desenvolvimento local no Brasil.

\footnotetext{
${ }^{1} \mathrm{O}$ conceito de clusters industriais refere-se à emergência de uma concentração geográfica e setorial de empreendimentos, a partir da qual são geradas externalidades produtivas e tecnológicas. Partindo da ideia simples de que as atividades empresariais raramente encontram-se isoladas, o conceito de cluster busca investigar atividades produtivas e inovadoras de forma integrada à questão do espaço e das vantagens de proximidade (Altenburg e Meyer-Stamer, 1999; MeyerStamer, 2001).

${ }^{2} \mathrm{O}$ conceito de experimentalismo difuso que adotamos foi desenvolvido por Silveira, Bocayuva e Zapata (2001).
} 
Este artigo inicia-se com uma breve reflexão teórico-conceitual sobre desenvolvimento local, seguida por uma apresentação dos antecedentes e por uma periodização e contextualização da ação dos governos municipais no desenvolvimento local no país, focalizando-se a articulação entre desenvolvimento local e processos participativos. Com isso, pretende-se resgatar determinadas experiências e trajetórias em seus contextos para facilitar a compreensão do presente e orientar a reflexão sobre possibilidades de alternativas futuras. Em seguida são apresentadas e analisadas as experiências e, por fim, as conclusões.

\section{Nota metodológica}

As experiências foram selecionadas, visitadas e analisadas. A seleção foi feita a partir da "rede de bancos de dados em gestão local", composta por bancos de dados sobre experiências em gestão local de diversas instituições nacionais (Brasil), entre as quais: Programa Gestão Pública e Cidadania (PGPC/Eaesp/ FGV), Observatório de Políticas Urbanas e Gestão Municipal (Ippur/UFRJFase), Rede de Comunicação de Experiências Municipais (Recem/Cepam) e o banco de dados do Instituto Pólis.

Os principais critérios para selecionar as experiências foram suas inserções em redes sociais e seus resultados econômicos, ou seja, seus resultados em termos de geração, distribuição e acumulação de renda e riqueza na região em que está inserida. Outros critérios também foram utilizados na seleção e podemos destacar entre os mais expressivos a representatividade regional da experiência e os respectivos atores sociais que lideraram seu desenvolvimento.

Vale deixar claro que as experiências analisadas nesse artigo não têm a intenção de compor um mapa com a totalidade da riqueza de experiências espalhadas pelo Brasil, mas conseguem representar experiências das três regiões mais importantes do país (Nordeste, Sudeste e Sul), excluindo as regiões Norte e Centro-Oeste por causa de dificuldades operacionais tanto de custo quanto de deslocamento dos pesquisadores. A pesquisa também consegue abranger experiências tanto do espaço urbano quanto do espaço rural, mostrando como é possível constituir arranjos produtivos nas mais variadas regiões do país.

Essas experiências, seus resultados positivos e seus limites servem para indicar horizontes e possibilitar reflexões sobre a adoção de alguns instrumentos de gestão social do desenvolvimento (quadro 2). Nesse sentido, a função 
das práticas é ampliar o espectro do possível através do reconhecimento da experimentação e da reflexão acerca de alternativas (Santos e Rodríguez-Garavito, 2006; Martins, Vaz e Caldas, 2008). Por conta dos objetivos deste artigo, não se pretende fazer aqui grandes formulações teóricas.

\section{Visões de desenvolvimento local}

A tarefa de comparar experiências de desenvolvimento local é exigente. O desenvolvimento local é um tema que suscita controvérsias e sobre o qual é difícil reunir consensos, tanto no Brasil quanto no debate internacional (Martins e Caldas, 2009a, 2009b; Martins, Vaz e Caldas, 2007). A profusão de visões não representa somente um debate acalorado nos meios acadêmicos e intelectuais. É também fruto de uma crise substantiva do conceito e da prática do desenvolvimento. $\mathrm{O}$ excesso de adjetivos ao substantivo desenvolvimento (local, sustentável, territorial, sustentado, integrado, democrático, participativo, entre outros) prova que este, de algum modo, perdeu parte do vigor e do seu sentido vetorial.

O tema do desenvolvimento local não é apenas controverso em termos conceituais, mas também metodológico. Assim colocado, tentativas de avaliar ou medir o desenvolvimento econômico produzido pelas intervenções locais tornam-se uma tarefa, no mínimo, difícil (Maluf, 2000).

Há quem diga que as experiências de desenvolvimento local são apenas a expressão espacial de um novo arranjo industrial "pós-fordista" (Benko e Lipietz, 1994). Há quem diga, por outro lado, que as experiências de desenvolvimento local têm dinâmicas próprias e não são apenas o reflexo da reorganização internacional do capital (Bacattini, 1994). Há ainda quem acredite no local como espaço privilegiado para experimentações contra-hegemônicas (Santos e Rodríguez-Garavito, 2006).

Segundo Benko e Lipietz (1994), duas revoluções na organização dos processos de desenvolvimento foram capazes de inverter a tendência de uma nova organização espacial (desordenada) da produção industrial. A primeira delas afetou as relações profissionais entre capital-trabalho. Com a crise do taylorismo pós-guerra, a saída encontrada foi a mobilização dos recursos humanos que se formavam não somente nas empresas, mas sobretudo na cultura local, na tradição familiar, em suma, num sistema local em que se enriqueciam as competências técnico-profissionais. A segunda está relacionada com a organização industrial, a relação entre as empresas. Redes de empresas ligadas por relações de parceria e subcontratação substituíram as grandes empresas 
integradas. Essas dinâmicas operam o regresso ao que era comum na geografia econômica do passado: os distritos industriais, em que se concentravam empresas do mesmo ramo, dividindo trabalho e partilhando um saber-fazer local (Altenburg e Meyer-Stamer, 1999).

Por outro lado, há quem defenda certa autonomia do local. Bacattini (1994), em sua análise socioeconômica dos distritos industriais, ressalta o seu sistema de valores e de pensamento homogêneo - expressão de uma ética do trabalho e da atividade, família e da mudança - condicionando os principais aspectos da vida local. Paralelamente a esse sistema de valores, desenvolveuse um conjunto de instituições, normas e regras destinadas a propagar esses valores a todo o distrito, estimulando sua adoção e a transmissão de geração em geração. Essas instituições incluem não só o mercado, a escola e a Igreja, como também as autoridades e organizações políticas locais, além de inúmeras outras instâncias das esferas públicas e privadas, em termos econômicos, políticos, culturais, religiosos e de solidariedade social. Para que tais dinâmicas sociais possam funcionar sem obstáculos, as instituições que integram o distrito devem, quando possível, respeitar o mesmo sistema de valores e regras. Isso não elimina os conflitos de interesse entre seus diversos membros, nem retira a consciência deles, mas institui esses conflitos num contexto de superioridade do interesse comunitário como princípio-base interiorizado pelo conjunto da sociedade de determinado território.

Santos e Rodríguez-Garavito (2006) propõem o conceito de um desenvolvimento local de base, "de baixo para cima". A capacidade de decidir sobre esse desenvolvimento não é entendida como algo de exclusividade do Estado ou das elites econômicas locais. Os autores enxergam na sociedade civil o ator principal desse processo de construção coletiva. Tal processo cria um potencial para que o efeito econômico dessas experiências chegue à esfera política e produza um ciclo de crescimento que contrarie as lógicas de exclusão socioeconômica e política.

O desenvolvimento local também apresenta vários significados, comportando as diferentes dimensões em que se exerce a cidadania, e tem condições de criar um espaço de interação entre cidadãos, recuperando a iniciativa e a autonomia na gestão do que é público. Essa concepção não admite modelos paradigmáticos de desenvolvimento local.

No caso de Oliveira (2001) é interessante notar a construção do autor em relação à ideia de um "subdesenvolvimento local". Seguindo seu raciocínio, isso implica pensarmos em duas advertências. A primeira afirma que nem sempre a existência do desenvolvimento é resultado da evolução em relação a uma condição anterior de subdesenvolvimento, mas é dada historicamente 
por relações entre nações, ou mesmo regiões. A segunda advertência diz respeito à especificidade do contexto e da condição brasileira. Tratar as questões do desenvolvimento local tendo como referência a França ou a Inglaterra é diferente de tratar do mesmo tema no Brasil, país dependente e periférico. $\mathrm{O}$ perigo está presente quando o desenvolvimento local tende a substituir a cidadania. Quando o conceito tende a ser utilizado como sinônimo de cooperação, de negociação, de convergência de interesses, de apaziguamento do conflito. O desenvolvimento local, em muitas versões, é o nome do público não estatal. Em nome de novos empregos e do aumento de renda, privatiza-se o público e retira-se do lugar a memória, a cultura do local via a acumulação primitiva do capital (Oliveira, 2001:24).

\section{Contextualização}

No Brasil, a valorização do local como instância privilegiada para planejar e executar políticas públicas de desenvolvimento remonta aos anos 1970. Não se tratava de prática recorrente, dado o contexto altamente centralizador e autoritário da época. Eram experiências pontuais como as ocorridas em Lages (SC) e Boa Esperança (ES). Vaz e Caldas (2006) propõem uma periodização para as experiências brasileiras de desenvolvimento local no período pós-redemocratização. A fase inicial, chamada de "antecedentes", correspondente ao período 1976-1988, ou seja, entre os primeiros sinais de distensão do regime autoritário até a promulgação da Constituição Federal de 1988. Essa fase é caracterizada pela existência de um pequeno número de experiências de resistência que têm o mérito de trazer uma maior articulação entre políticas territoriais e desenvolvimento local. Nesse período, tratava-se de uma manifestação que ocorria paralelamente ao processo de democratização do país, com suas disputas políticas e ideológicas.

No período (1976-1988), destacaram-se experiências que articulavam um conjunto de políticas setoriais territorialmente localizadas com a preocupação de promover a participação efetiva da comunidade (Alves, 1980). O desenvolvimento local, no contexto de luta pela democracia, serviu como instrumento demonstrador de que as instâncias subnacionais possuíam capacidade para promover o desenvolvimento em moldes alternativos aos grandes projetos desenvolvimentistas que caracterizaram o modelo centralizador e subordinador implantado durante o regime militar. Ocorreram em um contexto de desaceleração econômica e permanência do regime autoritário, ou de suas marcas, em âmbito nacional. 
As experiências dos anos 1970 e 1980 serviram como referências para aqueles que acreditavam ser possível instituir novas práticas na gestão pública local, demonstrando a possibilidade de se fazer resistência a partir do nível local, apesar de diferenças contextuais e conceituais do que seja o próprio local. Na época, o papel das câmaras municipais era limitado, os municípios não eram entes da federação, não possuíam leis orgânicas municipais, tinham pouca autonomia fiscal, tributária e sofriam com a escassez de recursos transferidos dos governos federal e estaduais. No plano nacional, predominavam os grandes projetos desenvolvimentistas.

Nesse contexto de pouca autonomia, as vozes de resistência não distinguiam "local" de "municipal". As lutas no plano nacional eram para municipalizar as políticas públicas. No âmbito local, as experiências inovadoras concentravam-se em descentralizar a gestão, em buscar formas de democratizar as relações do Estado com a sociedade. Não se tratava propriamente de encontrar alternativas locais de desenvolvimento econômico. Nem por isso, deixou-se de experimentar no âmbito da economia, instância recortada pela preocupação com a geração, distribuição e acumulação de renda e riqueza.

Segue-se a essa fase uma segunda, chamada por Vaz e Caldas (2006) de "a grande encruzilhada", que inclui o período 1989-1992 e corresponde ao mandato das primeiras gestões municipais após a promulgação da Carta de 1988. A partir de 1989, os municípios tiveram sua capacidade tributária e fontes de financiamento ampliadas. Essa situação permaneceu até 1996. Além disso, a nova Constituição redefiniu e expandiu as atribuições dos municípios e sua autonomia no quadro federativo brasileiro. Nessa fase, ocorreu a conquista de prefeituras importantes por setores de forte oposição à ditadura e mesmo ao novo governo do período de redemocratização (Partidos dos Trabalhadores - PT). Isso significou a entrada de novos atores políticos nas instâncias decisórias locais, com fortes pressões para o atendimento de demandas sociais reprimidas.

Nesse quadro, a participação dos municípios nas ações do Estado tornou-se mais visível. Entretanto, os municípios, apesar de seu novo papel e das novas receitas com as quais passaram a contar, não desenvolveram um projeto de inserção na federação que privilegiasse seu papel de articuladores e protagonistas do desenvolvimento local. Ao contrário, as pressões por atendimento às demandas reprimidas de infraestrutura urbana básica, serviços públicos e políticas sociais consumiram a maior parte da energia dos governantes municipais e dos recursos disponíveis nos municípios. Ao mesmo tempo, o governo federal não atuava de modo a valorizar qualquer centralidade dos municípios no desenvolvimento local. Na verdade, nesse momento o desenvolvimento foi 
excluído da agenda governamental federal e estadual por conta da luta contra a inflação e os crescentes déficits fiscais nas contas nacionais. Esse período também marca o começo da influência do pensamento neoliberal e das políticas econômicas de ajuste e base monetarista no país.

A partir de 1993 inicia-se a terceira fase, intitulada "o despertar tardio". Nela, ganha ainda mais centralidade um estilo de governo local caraterizado como gestor de crises sociais, executor de políticas sociais e de infraestrutura básica. A dimensão de um projeto de desenvolvimento local é pouco a pouco afastada da cena política. Em um cenário adverso do ponto de vista macroeconômico, impõem-se tentativas locais de desenvolvimento. A saída imediata encontrada pelas administrações públicas locais foi a isenção fiscal e a intensificação de uma guerra fiscal entre municípios, que caracterizou um "hobbesianismo municipal" (Melo, 1996) com consequências nefastas sobre a própria administração pública, que se via alijada de recursos necessários para executar políticas públicas e não conseguia gerar empregos suficientes para a população local. A crise nacional recaiu sobre os municípios que, no máximo, conseguiram realizar alguma política compensatória, mas sem influência sobre as políticas monetária e salarial e tampouco representação em importantes centros decisórios que se consolidavam no país, como o Conselho de Política Monetária do Banco Central (Copom), por exemplo.

Além das primeiras tentativas de conter a crise do desemprego por meio das isenções fiscais, muitos municípios, mais criativos, instituíram bancos do povo como meio de financiar pequenos empreendimentos a taxas de juros menos extorsivas que as praticadas no mercado bancário; fomentaram cooperativas; instituíram cursos de formação e de qualificação profissional; estabeleceram parcerias com outros países em torno de projetos técnicos e buscaram a conquista de outros mercados por meio de iniciativas de comércio justo e solidário. Alguns poucos viram o orçamento municipal como importante instrumento para induzir a demanda por meio das compras públicas governamentais (Singer, 2000). Nesse contexto surgem várias experiências, algumas induzidas pelo próprio governo, outras encabeçadas por setores progressistas da sociedade civil.

Ganha centralidade, então, um arsenal de instrumentos de intensificação da participação, desarticulado de um projeto mais amplo de desenvolvimento (Vaz e Caldas, 2006; Martins, Vaz e Caldas, 2007, 2008; Martins e Caldas, 2009a, 2009b). As experiências de políticas públicas locais "inovadoras", que floresceram a partir dos anos 1980, passam a compor um repertório a ser combinado e replicado por gestores públicos municipais, multiplicando-se intensamente. $\mathrm{O}$ foco tornou-se variado, sem necessaria- 
mente contar com uma articulação entre essas iniciativas ou, ao menos, sem desenhar uma estratégia de desenvolvimento. A preocupação anterior com valores democráticos, o desenvolvimento econômico alternativo e a valorização da dimensão territorial, de algum modo, perderam centralidade para práticas que apenas poderiam ser consideradas modernizadoras (Vaz e Caldas, 2006; Martins, Vaz e Caldas, 2008).

Ao longo desse período, observa-se uma reconcentração da carga tributária nas mãos do governo federal, a redução das receitas financeiras dos municípios e o aumento de pressão por gastos sociais assumidos em um contexto de expansão do desemprego e reconversão da base econômica. Nesse contexto, a ideia de desenvolvimento local voltou à tona, descontextualizada da dinâmica do território e das propostas de aprofundamento da democracia. Nos discursos e nas práticas surge uma visão de desenvolvimento local sem maior embasamento social e conceitual, surgida como resposta à crise do emprego e à perda de dinamismo econômico, reduzindo-se muitas vezes somente à geração de emprego e de renda no âmbito local (Vaz e Caldas, 2006; Martins, Vaz e Caldas, 2007, 2008).

As iniciativas que foram constituídas nesse movimento foram caracterizadas como um tipo de experimentalismo difuso (Silveira, Bocayuva e Zapata, 2001). Diversos tipos de instrumentos de intervenção foram utilizados (quadro 2), mas essa profusão de iniciativas e o repertório de práticas construídas não se ancoravam em um projeto de desenvolvimento claramente estruturado, tanto em termos nacionais quanto em termos do papel do desenvolvimento local nesse projeto.

\section{A articulação entre o desenvolvimento local e os processos participativos}

A chave para analisar as experiências de desenvolvimento local em articulação com os processos participativos é considerar sua incidência no combate à desigualdade. A participação apresentou-se, para parte das forças políticas que assumiram governos municipais com a redemocratização, como uma estratégia fundamental para a redistribuição de poder, riqueza e renda (Martins e Caldas, 2009a, 2009b). Nos discursos desses grupos, a participação dos cidadãos seria a garantia para a inversão de prioridades tradicionalmente adotadas pelos governos, em direção a privilegiar os setores empobrecidos e mais excluídos. 
Assim, destacaram-se as experiências baseadas no orçamento participativo, ${ }^{3}$ estruturado em base geográfica e temática. A experiência de Porto Alegre é a mais conhecida (Cabannes, 2004). Iniciada em 1989, expande-se por inúmeros municípios ao longo dos anos seguintes e mantém-se em Porto Alegre até a presente data (2010), mas já enfraquecido e sem a força original. O primeiro período do orçamento participativo em Porto Alegre (1989-1992), de alguma maneira, busca, por meio da participação, articular um projeto de desenvolvimento local com a dimensão territorial, circunstanciada na esfera de lutas democráticas. As 16 regiões que definiam a base geográfica de organização orçamentária foram definidas num acordo entre governo e movimento comunitário, levando em conta os critérios de afinidade política e cultural entre a população (Cabannes, 2004). Nessa base, além de definir suas prioridades (em termos de obras e infraestrutura) e escolher seus representantes junto ao Conselho Municipal de Orçamento Participativo, a população ainda discutia o orçamento municipal em sua base temática (educação, saúde, cultura, desenvolvimento econômico, política tributária, entre outras).

A implementação do orçamento participativo em Porto Alegre considerou a necessidade de conciliar as dimensões política e econômica: distribuir renda sem socializar a política é muito pouco e pode ensejar certo tipo de paternalismo, que é nocivo à afirmação da autonomia dos indivíduos e das organizações de base da sociedade. Socializar a política, sem tocar na renda, pode promover o desalento com a própria eficácia da luta política e a "retirada" das pessoas para o âmbito cada vez mais privado das suas existências (Baiocchi, 2005).

O debate em torno do orçamento municipal e da definição de prioridades municipais com participação popular entra na agenda de diversos governos do país e é amesquinhado na medida em que o amplo debate proposto em Porto Alegre é reduzido à constituição de um "plano de pavimentação, obras e infraestrutura" elaborado participativamente (Martins, Vaz e Caldas, 2008). As políticas setoriais e sua articulação com o território a partir do orçamento participativo e o debate em torno da geração da renda que, em última instância, define quem paga a conta da gestão local, foram abandonados.

$\mathrm{O}$ orçamento participativo poderia ter sido a ferramenta que permitiria o reencontro da articulação de políticas setoriais e do território em torno

\footnotetext{
${ }^{3}$ Existe uma vasta literatura sobre orçamento participativo (OP). Entre muitos, ver Avritzer e Navarro (2008); Avritzer (2009); Marquetti, Campos e Pires (2008); Wampler e Avritzer (2005).
} 
de um projeto local de desenvolvimento. Entretanto, isso não aconteceu: o orçamento participativo foi visto como instrumento de democratização da gestão, redistribuição de poder, identificação de demandas, de prestação de contas do governo e mecanismo de decisão com relação a uma pequena parte dos recursos públicos municipais (Cabannes, 2004; Vaz e Caldas, 2006). Mas não foi suficiente como articulador de processos mais amplos de desenvolvimento local. Essa insuficiência não é apenas do orçamento participativo. Como as experiências analisadas a seguir demonstram, embora o elemento participativo estivesse presente, notadamente pela articulação de atores da sociedade civil, a participação não aparece como substrato para o desenvolvimento local em sua dimensão econômica, especialmente em iniciativas governamentais.

\section{As experiências}

A constituição do Polo Moveleiro de Votuporanga (SP) é uma experiência que não conta com a participação ativa e central do governo, seja municipal, estadual ou federal. Trata-se de uma iniciativa dos empresários locais do setor moveleiro.

O setor moveleiro é tradicional na região Noroeste do estado de São Paulo e tem empresários estabelecidos em Votuporanga desde meados dos anos 1950. Apesar da tradição, o setor moveleiro do Noroeste paulista não possuía uma política deliberada de fortalecimento de suas atividades. A iniciativa de constituição de um polo se inicia em meados da década de 1990, quando os empresários do setor decidiram criar a Associação Industrial da Região de Votuporanga. Com isso, eles desvincularam-se da Associação Comercial e Industrial que direcionava suas ações para o comércio, setor mais organizado e mais tradicional da região.

Uma vez organizados em associação, os industriais realizaram um diagnóstico e constataram que seus principais problemas estavam relacionados à baixa qualidade da mão de obra, seja em termos da produção, seja em termos da gestão, e com a ausência de uma política de qualidade do produto. Como forma de enfrentar o problema, os empresários estabeleceram parcerias com várias instituições locais, estaduais e nacionais, o que culminou na criação do Centro Tecnológico do Mobiliário, que atua na área de formação e qualificação da mão de obra para o setor de móveis. Dessas parcerias resultou também um consórcio para abertura de uma frente de exportações. 
A constituição do Polo Moveleiro de Votuporanga demonstra que é possível induzir uma ação coletiva ${ }^{4}$ com ganhos e benefícios para os envolvidos. A experiência demonstra a capacidade de articulação interna e externa do setor em relação ao local, mas não fica claro se esse setor é pujante o suficiente para induzir desenvolvimento, seja no município de Votuporanga, seja na região do Noroeste paulista.

O Polo Moveleiro do Estado do Rio Grande do Sul (RS), na região das Serras Gaúchas, diferentemente da iniciativa paulista, foi induzido por uma ação governamental do Estado do Rio Grande do Sul. Apesar da considerável organização industrial da região, concentração regional da cadeia produtiva, importantes instituições de ensino e pesquisa e proximidade com centros consumidores como a região metropolitana de Porto Alegre, o setor moveleiro não teve capacidade de articular um projeto comum ou constituir uma associação com objetivos de promover o desenvolvimento e o fortalecimento do setor. Essa incapacidade talvez seja resultado da discrepância tanto de organização quanto de lucro e rentabilidade entre os muitos pequenos produtores da região e a pequena quantidade de grandes produtores. Essa diferença gera desconfiança entre os atores e certa inércia de iniciativas.

Com base na lógica da ação coletiva de Olson (1999), a ação só viria se uma grande empresa percebesse que a organização do setor lhe traria uma lucratividade suficiente para saldar o custo da organização setorial; ou se um ator externo induzisse a ação. As explicações da teoria da ação coletiva partem do pressuposto de que os indivíduos são atores intencionais, que perseguem objetivos específicos. Para Olson (1999), os indivíduos não farão parte de grupos que lutam por um bem público, a menos que haja coação, ou sejam estimulados mediante algum bem privado. Assim, estabelecer-se-ia o problema da ação coletiva ou o problema do free rider. Quando uma pessoa conta com a possibilidade de beneficiar-se da ação coletiva dos demais, sem sofrer os custos da participação, tem um grande incentivo para comportar-se isoladamente. Pode-se dizer, portanto, que o problema da ação coletiva aparece quando o interesse privado sobrepõe-se à obtenção do bem público.

A lógica da ação coletiva se assemelha, na opinião de Olson (1999), à lógica do mercado. Desse modo, o autor salienta a dificuldade de passar mecanicamente dos interesses individuais à ação coletiva. Sua tese central é a seguinte: quanto maior for o grupo, menor será o incentivo individual para perseguir o bem coletivo. Ou seja, a menos que o grupo seja pequeno, aos in-

\footnotetext{
${ }^{4}$ Ver Olson (1999).
} 
divíduos racionais não interessa cooperar para conseguir um bem coletivo. As dificuldades de organizar os interessados para alcançar um bem público são diretamente proporcionais à amplitude dos objetivos e ao número de interessados. A ação coletiva é mais eficaz quanto mais limitado forem os interesses e menos numerosos os interessados. Em outros termos, os pequenos grupos com interesses focalizados são os mais eficazes para conseguir bens públicos para os seus integrantes. Os grupos grandes só conseguirão mobilizar-se para obter um bem público se forem oferecidos incentivos seletivos para os indivíduos. Tal mobilização, portanto, não é produto direto do interesse individual por um bem público. Olson (1999) supõe, então, que a própria existência do grupo é determinada pelos bens privados que oferece, e não por ele oferecer um bem público.

Ainda no trabalho do autor, aparece a categoria do grupo latente, que tem uma grande tradição dentro do pensamento sociológico. Com essa definição, explicam-se aqueles grupos existentes na sociedade que não estão mobilizados em torno de um objetivo ou de um projeto comum, ainda que eles possam ser determinados e existam. Na teoria proposta, é nesse tipo particular de grupo que os incentivos seletivos (estímulos), ou os constrangimentos externos (coação) desempenham um papel crucial, pois se apresentam como a única forma de mobilizar o próprio grupo em questão (Olson, 1999).

No caso do setor moveleiro gaúcho, a organização setorial foi induzida por um ator externo: o governo estadual. Coube ao governo liderar o processo de estabelecimento de parcerias, elaboração de diagnóstico e definição das ações. Também coube ao governo integrar o pequeno ao grande produtor. Mais do que isso, a organização setorial ocorreu, como propôs e queria o governo estadual, por meio de sua Secretaria de Desenvolvimento e Assuntos Internacionais, com o uso de uma pedagogia pautada em relações de cooperação e solidariedade.

Da ação governamental resultou o aumento da confiança entre os atores envolvidos e deles com relação ao próprio governo, além da elaboração coletiva de um plano de ação abrangente e capaz de inserir o setor num arranjo produtivo que envolvesse, além da formação e aquisição de matéria-prima, a percepção de que maquinários e equipamentos majoritariamente importados poderiam ser substituídos pelos nacionais, o que implicaria redução tanto de investimentos quanto de manutenção. Em termos nacionais ou do estado do Rio Grande do Sul, essa percepção, quando praticada, contribuiu com o aumento de investimentos na indústria nacional e com o aumento do superávit no balanço de pagamentos.

Outra experiência gaúcha analisada neste artigo diz respeito à Incubadora Tecnológica do Setor Coureiro-calçadista do Estado do Rio Grande do 
Sul (RS), setor que está concentrado no Vale dos Sinos, região metropolitana de Porto Alegre, que responde por $40 \%$ da produção nacional e $80 \%$ das exportações brasileiras do setor. ${ }^{5} \mathrm{~A}$ experiência analisada, no entanto, não se preocupou com as grandes empresas exportadoras, mas com a produção de tecnologia (principalmente design) voltada em grande parte para as pequenas empresas e para as cooperativas de produtores. Trata-se, portanto, de um duplo desafio: tornar as cooperativas produtivas e viáveis por meio de tecnologia própria a partir da valorização do fator de produção trabalho, ou seja, a partir da valorização das pessoas envolvidas no processo produtivo.

Nesse caso, também coube ao governo iniciar a articulação da rede de parceiros e colaboradores e aportar recursos. Com isso, foram estabelecidos prédios bem equipados para abrigar duas linhas de produção e um centro de desenvolvimento de design - Centro Integrado de Inovação em Design.

Todavia, durante pesquisa de campo, verificou-se que o prédio estava subocupado e as cooperativas endividadas. No curto prazo, não foi possível conciliar os dois objetivos apontados: a lógica produtivista do capitalismo tradicional e a constituição de laços pautados na solidariedade e na cooperação. Pode-se cogitar que o resultado esteja relacionado ao próprio "cluster" escolhido para implementação de uma prática solidária: um "cluster de sobrevivência" caracterizado por um conjunto de microempresas de subsistência com determinadas características: capital social modesto, grande desconfiança entre empresas e concorrência ruinosa combinada à baixa capacidade de inovação (Altenburg e Meyer-Stamer, 1999; Meyer-Stamer, 2001).

Os resultados aferidos também podem estar relacionados com o tempo da iniciativa. A lógica temporal do governo é condicionada pelo calendário eleitoral. Já a lógica de mudança de mentalidade, de construção de capital social e fortalecimento de laços de confiança, às vezes, demora décadas. Provavelmente vêm daí as limitações dos resultados encontrados e a impossibilidade de uma avaliação mais crítica dos resultados.

Ainda no Rio do Grande do Sul (RS), analisou-se a experiência da Cooperativa dos Citricultores Ecológicos do Vale do Caí (Ecocitrus). Por conta do trabalho de organizações da sociedade civil e de movimentos ambientais e ecológicos, o estado gaúcho apresenta acúmulos em relação à consciência da população em torno desses temas. Soma-se a isso a tradição da agricultura familiar, associativismo e a capacidade de resolução compartilhada de problemas da comunidade para o sucesso da cooperativa. Sua origem está

\footnotetext{
${ }^{5}$ Dados do IBGE, Cadastro Central de Empresas (2003).
} 
no Prorenda, um projeto específico da Cooperação Técnica Alemã (GTZ), que evoluiu para diversas atividades. Destaca-se o gerenciamento de uma grande usina de compostagem, uma central de beneficiamento de frutas, além do desenvolvimento de pesquisas agroecológicas.

A experiência tentava superar o problema do modelo tecnológico adotado na região. A microrregião do Vale do Caí caracterizava-se pela agriculta familiar, diversificada e autossuficiente. A citricultura, forte na região, era dependente de agroquímicos e de uma lógica de mercado que fugia ao controle dos agricultores. Nos anos 1980, a decadência da citricultura e a queda de produtividade provocaram o êxodo da mão de obra jovem da região para os grandes centros urbanos.

O principal objetivo da cooperativa Ecocitrus foi desenvolver uma agricultura orgânica, viabilizando a produção do pequeno agricultor sem agredir o meio ambiente. Para isso, a cooperativa expandiu sua atuação para várias frentes: uma usina de compostagem, uma central de beneficiamento e agroindústria, trabalhos de formação e capacitação em agroecologia, pesquisa e extensão em temas como microbiologia de alimentos, compostos orgânicos e manejo ecológico.

A adoção da agricultura ecológica se ampliou consideravelmente no Vale do Caí. Eles atuam fortemente na disseminação de sua tecnologia social e avançam na construção de novos mercados para seus produtos, atraindo parceiros e grupos agroecológicos nacionais e internacionais.

A quinta experiência apresentada neste artigo é a apicultura em Simplício Mendes, no Piauí (PI), que articula a produção de mel e seus derivados, realizada por várias comunidades localizadas no semiárido nordestino. A iniciativa de organização das comunidades de produtores, da formação de uma associação e construção de um entreposto para comercialização de mel não parte nem do governo, nem de um grupo de empresários, mas de um padre, líder da paróquia, e das próprias comunidades que se reuniam em torno das celebrações e atividades promovidas pela Igreja Católica da Diocese de Floriano (PI).

Trata-se de um longo processo histórico que reúne inúmeras intervenções, passando pela compra e financiamento de lotes para fixação do homem à terra, pela consolidação de 17 comunidades de produtores, pela resolução de problemas como a falta de água e de alimentos por meio da construção de açudes, cisternas e produção de roças e criações variadas.

Somente depois surge a produção do mel como complemento alimentar e fonte alternativa de renda para complementar o orçamento familiar, larga- 
mente empenhado em produtos ligados à alimentação (farinha, sal e açúcar). De complemento alimentar, o mel passou a produto excedente para a venda.

As principais lideranças de todo esse processo são o padre Jeroen, radicado no sertão há mais de 30 anos, e Anchieta, uma das principais lideranças leigas da região. A constituição da associação e a qualificação da produção do mel e seu escoamento para os mercados interno e externo estão amparados numa intensa rede de colaboradores e parceiros.

O principal elemento que garante o sucesso foi o processo de convencimento (demorado) de que é possível melhorar de vida trabalhando coletivamente e relacionando-se com a terra, mesmo numa região em que predomina seu estado seco e árido. Outro elemento que pode ser explicativo do sucesso da experiência é o tempo de execução de cada uma das etapas. Não se tratou de tempo subordinado à lógica do capital, nem à lógica política ou institucional, mas de um tempo próprio da comunidade e de sua população, ou seja, de longo prazo, medido em décadas.

Os resultados são palpáveis: melhoria da qualidade de vida, aquisição de bens de consumo duráveis, melhora da autoestima, aumento da exigência da qualidade de produtos na condição de consumidor, consciência da necessidade de negociar e se reunir para organizar os esforços coletivos, e do ponto de vista mais mercadológico, abertura e conquista de mercados internacionais por meio do mercado solidário.

Entretanto a experiência tem limites evidentes. A relação com o poder público e os coronéis da região é difícil, assim como a formação de novas lideranças. O processo de formação é contínuo. Segundo o próprio padre Jeroen, ${ }^{6}$ não se espera transmissão automática de consciência da importância e da prática da ação comunitária. Esses valores devem ser trabalhados permanentemente.

O caso de Simplício Mendes é patente para mostrar como nem sempre é a existência de capital social que redunda em desenvolvimento local, mas a prática cotidiana e persistente de ações orientadas para o desenvolvimento local também é capaz de criar e mobilizar o capital social.

O conceito de capital social é tratado amplamente em trabalhos clássicos como Bourdieu $(1980,1985)$ e Coleman (1990). Mais recentemente, Putnam (1996) tratou do tema ao estabelecer relações entre a constituição de capital social e as mudanças institucionais ocorridas na Itália ao longo dos anos 1970. Segundo Putnam (1996), capital social refere-se ao conjunto de normas

${ }^{6}$ Dados coletados durante visita de campo. 
de confiança mútua, às redes de cooperação, aos mecanismos de sanção e às regras de comportamento que podem melhorar o desempenho da sociedade na solução de problemas que exigem a ação coletiva. O capital social seria, então, um bem público, subproduto de outras atividades sociais, fundado em redes de cooperação horizontais e nas relações de confiança. Para o autor, mais importante que mudanças institucionais é a existência de capital social territorializado. O caso de Simplício Mendes mostra que redes sociais e articulações em torno de alguma instituição, ou práticas institucionais, são capazes de criar, ainda que de forma incipiente, capital social.

A iniciativa dos Minidistritos Industriais e de Serviços de São José do Rio Preto, no estado de São Paulo (SP), é a de construir um território destinado à instalação de pequenas empresas, ou pequenos empreendimentos comerciais com infraestrutura própria, no interior de loteamentos populares realizados pelo poder público, produzindo oferta de emprego e renda à população desses assentamentos e bairros, além de buscar aproveitar de forma mais regular e responsável o espaço urbano.

Pode-se dizer que se trata de uma solução integrada, já que combina um programa habitacional articulado a um programa de geração de emprego e renda por meio do estímulo à criação de micro e pequenas empresas. No início, a grande maioria dos empreendimentos era dedicada às empresas do setor moveleiro, de confecções e serralherias. Com o passar dos anos, ocorreu a introdução do setor de serviços e demais atividades comerciais.

A experiência dos minidistritos trouxe para o município de São José do Rio Preto (SP) impactos socioeconômicos positivos, como a regularização de várias empresas e o aumento da arrecadação de IPTU e de imposto sobre serviços de qualquer natureza (ISQN). Entretanto, são nos aspectos urbanísticos que estão os impactos mais visíveis da intervenção. A criação dos loteamentos populares com possibilidades de geração de emprego e renda inibiu o processo de formação de favelas, além de favorecer a queda dos índices de violência. A proximidade do local de trabalho tornou o custo de transporte baixo.

Apesar do aparente sucesso da experiência, uma análise mais cuidadosa demonstra algumas limitações do programa. As empresas praticamente só produzem produtos que empregam baixa tecnologia, utilizando maquinário obsoleto e de segunda mão. Além disso, muitos trabalhadores estão em situação precária e as indústrias apresentam altos índices de acidente de trabalho e poluição ambiental. O desenvolvimento econômico do município é insuficiente para transformá-lo em um polo econômico importante na escala regional e nacional e pouco contribui em termos de inovação tecnológica. 
Assim, pode-se dizer que os resultados apresentados pelos minidistritos são oriundos de algumas condições que pré-existiam ao programa. São José do Rio Preto (SP) sempre foi um município com alta capacidade empreendedora, com grande disponibilidade de terras aptas à urbanização. De qualquer forma, em termos econômicos, os resultados são baixos.

A experiência do Banco Palmas, da cidade de Fortaleza, no Ceará (CE), se autodenomina um banco de risco, pois trabalha com empreendedores que não oferecem condição de ser reconhecidos como clientes em instituições formais de crédito.

Localizado no Conjunto Palmeiras, bairro pobre da cidade de Fortaleza, a iniciativa começou com a organização da população em torno da Associação dos Moradores do Conjunto Palmeiras (Asmoconp), no início dos anos 1980 e da percepção de que faltava alguma coisa para o comércio do bairro crescer. Surgiu, então, a ideia de um banco. Atualmente, o Banco Palmas é o embrião de uma rede socioeconômica solidária, já em formação, que integra 19 bairros de Fortaleza, visando satisfazer o consumo local. Entre seus principais objetivos está o consumo solidário e a sustentabilidade dos pequenos empreendimentos locais. Ainda faz parte da iniciativa um clube de troca ${ }^{7}$ que trabalha com uma moeda social: o Palmares.

Devido à informalidade da experiência, é difícil mensurar com segurança os reais impactos econômicos, porém está claro que os resultados são positivos. A experiência é muito mais do que uma iniciativa de inclusão econômica, supera essa abordagem e demonstra a capacidade da comunidade de formular políticas ativas e democráticas. A própria criação de uma metodologia para um sistema solidário comprova isso.

A informalidade e a falta de um processo mais intenso de institucionalização são, sem dúvida, limitações da experiência que deverão ser trabalhadas prioritariamente no futuro. Atualmente também é possível constatar uma queda do nível de mobilização e de envolvimento da população, que necessita receber mais atenção da comunidade.

A experiência do Consórcio Intermunicipal de Produção e Abastecimento (Cinpra), capitaneado pela Prefeitura Municipal de São Luís (MA), focalizou-se na construção de um arranjo institucional colaborativo entre governos locais. A possibilidade de constituição de um consórcio entre municípios surgiu como solução de um problema de abastecimento regional. A avaliação que

\footnotetext{
${ }^{7}$ Para mais informações sobre o funcionamento do clube de trocas, ver França, Vaz e Silva (2002).
} 
se fazia era a de que a demanda por bens de consumo básicos em São Luís era atendida por produtos oriundos de outros estados, criando empregos em diversas localidades, mas não no próprio estado, além de significar um custo elevado de transporte e frete que restringia o acesso de boa parcela da população local.

A pergunta que permitiu que a constituição do consórcio entrasse na agenda foi: por que, ao invés de "importar" alimentos de outros estados, São Luís e os municípios vizinhos não produzem, beneficiam e vendem produtos alimentícios na própria região? Diante dessa situação, surgiu o Consórcio Intermunicipal de Produção e Abastecimento (Cinpra) de São Luís do Maranhão, em outubro de 1997, depois de meses de discussão com vários prefeitos de municípios próximos à capital maranhense.

Do ponto de vista organizacional, o Cinpra é dirigido pelo colegiado de prefeitos dos municípios (Conselho dos Prefeitos), que se reúne a cada três meses (o Conselho de Prefeitos elege um presidente e um vice-presidente); e é operacionalizado por uma secretaria executiva. Há também um conselho fiscal e o fórum permanente dos secretários municipais de agricultura, que se realiza uma vez por mês.

Uma das atividades mais importantes dos técnicos do Cinpra é o auxílio às secretarias de agricultura na elaboração, encaminhamento e acompanhamento de projetos de expansão e diversificação da produção.

Tais projetos destinam-se tanto à produção agrícola, com a introdução de novas modalidades de plantio, quanto à criação animal, como o projeto de caprinocultura e de piscicultura. Há também projetos relacionados ao aumento da produtividade das roças por meio da utilização de técnicas mais eficazes.

A experiência do Consórcio Intermunicipal do Grande $A B C$, em São Paulo (SP), de um lado evidencia as dificuldades que os municípios encontram para viabilizar a cooperação intergovernamental e, de outro, aponta caminhos para superar as dificuldades comuns a esse conjunto de municípios.

O consórcio é composto pelas sete prefeituras que compõem a região do Grande $\mathrm{ABC}$, correspondente à subregião sudeste da Região Metropolitana de São Paulo. Trata-se de região adensada, fortemente afetada pela rápida industrialização e pelo crescimento urbano desordenado e, nas últimas décadas, pelo desemprego e desindustrialização relativa. Os municípios do Grande ABC forjaram a ideia de uma união estratégica, capitaneada pelo então prefeito de Santo André, Celso Daniel, ao longo dos anos 1990. A região já havia construído uma identidade regional, em função do seu processo de industrialização e desenvolvimento econômico.

Mesmo nos momentos de certa desmobilização, a ideia de forjar soluções regionais também foi assumida por vários segmentos da sociedade civil, 
e expressa na criação do Fórum da Cidadania do Grande $A B C$, que congregou associações empresariais, sindicatos de trabalhadores, grupos ambientalistas, associações de moradores, entre outros.

Em 1997 foi criada a Câmara Regional do Grande ABC, como estratégia para estimular o desenvolvimento econômico local. A Câmara conta com três instâncias - conselho deliberativo, coordenação executiva e grupos temáticos -, estes últimos dedicados aos seguintes assuntos: desenvolvimento econômico e emprego; planejamento urbano e meio ambiente; desenvolvimento social; e temas administrativos e financeiros. Cabe aos grupos temáticos elaborar diagnósticos e recomendações de ações, além de políticas para o desenvolvimento da região. A câmara não tem personalidade jurídica, nem orçamento anual fixo. Funciona na sede do Consórcio do Grande ABC, que lhe garante o apoio administrativo necessário. Os integrantes dos grupos são funcionários das prefeituras ou dos vereadores de municípios envolvidos que cedem esses profissionais.

O primeiro desafio enfrentado pela Câmara Regional do Grande ABC foi priorizar as inúmeras propostas surgidas das discussões dos grupos, envolvendo processos participativos amplos. Uma das propostas aprovadas foi a criação de uma agência de desenvolvimento regional, implementada em outubro de 1998, para desempenhar o papel de braço executivo da Câmara Regional. Constituiu-se como organização não governamental, mantida por um corpo de associados (o Consórcio do Grande ABC, com 49\% e entidades e empresas do setor privado, com 51\%), o que lhe assegura maior autonomia financeira. Uma síntese das experiências é apresentada no quadro 1.

Quadro 1

\section{Distribuição de experiências analisadas por região e setor}

\begin{tabular}{|lll|}
\hline Experiência & Região & Setor \\
\hline Polo Moveleiro de Votuporanga & $\begin{array}{l}\text { Região Noroeste Paulista, foco } \\
\text { município Votuporanga (SP) }\end{array}$ & Moveleiro \\
Polo Moveleiro do Estado do & Região das Serras Gaúchas (RS) & Moveleiro \\
Rio Grande do Sul & Vale dos Sinos, Região Metropoli- & Coureiro-calçadista \\
$\begin{array}{l}\text { Incubadora Tecnológica do } \\
\text { Setor Coureiro-calçadista do }\end{array}$ & tana de Porto Alegre (RS) & \\
$\begin{array}{l}\text { Estado do Rio Grande do Sul } \\
\text { Cooperativa dos Citricultores }\end{array}$ & $\begin{array}{l}\text { Vale do Caí, Rio Grande do Sul } \\
\text { Ecológicos do Vale do Caí }\end{array}$ & Citricultor \\
Apicultura em Simplício Mendes & Alto Médio Canindé, Sudeste do & Apicultor \\
(PI) & Estado do Piauí (PI) & \\
\hline
\end{tabular}

Continua 


\begin{tabular}{|lll|}
\hline Experiência & Região & Setor \\
\hline $\begin{array}{l}\text { Minidistritos industriais e de } \\
\text { serviços de São José do Rio Preto }\end{array}$ & São José do Rio Preto (SP) & Diversos, incluindo serviços \\
Banco Palmas, Fortaleza & $\begin{array}{l}\text { Conjunto Palmeiras, região pobre } \\
\text { de Fortaleza (CE) }\end{array}$ & Economia solidária, microfinanças \\
$\begin{array}{l}\text { Consórcio Intermunicipal de } \\
\begin{array}{l}\text { Produção e Abastecimento } \\
\text { (Cinpra) }\end{array}\end{array}$ & $\begin{array}{l}\text { MA) } \\
\begin{array}{l}\text { Consórcios Intermunicipal do Grande São Luís } \\
\text { Grande ABC }\end{array}\end{array}$ & $\begin{array}{l}\text { Produção e abastacimento de } \\
\text { alimentos }\end{array}$ \\
\hline
\end{tabular}

\section{Análise comparada: atores, instrumentos e gestão social do território}

Os casos estudados (quadro 1) evidenciam a variedade de estratégias e mecanismos de articulação de atores locais em torno do desenvolvimento local. Também deixam claro que o recurso aos instrumentos de promoção do desenvolvimento varia em função das estratégias e objetivos desses atores, além da influência das capacidades institucionais e sociais, e das dinâmicas políticas e sociais de cada contexto (quadro 2).

Do ponto de vista das iniciativas, viu-se que algumas experiências partiram do governo e outras de parcelas da sociedade civil - desde comunidades organizadas pela Igreja Católica até empresários que constituíram uma associação. Todas, no entanto, partiram da necessidade de definir e organizar parcela da sociedade interessada em atuar em determinado setor, ou de disputar parcela da renda socialmente gerada.

A presença de um ou mais atores sociais fortemente engajados, préexistentes ou constituídos ao longo do processo, configura-se como uma característica comum. No caso da Ecocitrus, a presença de um programa de uma agência de cooperação internacional aponta a importância que podem ter atores externos com grande capacidade de mobilização. Entretanto, vale a pena registrar que o programa da agência em questão encontrou condições propícias para sua implantação na região.

A articulação de atores sociais pressupõe um prazo de maturação e um custo de organização e de institucionalização. Percebe-se que os setores mais organizados e com resultados mais concretos tiveram mais tempo de maturação e de organização: são os casos de Votuporanga e de Simplício Mendes. Isso não quer dizer que o tempo é condição suficiente, mas, sim, que permite reunir capacidades institucionais, formular consensos e construir relações de confiança que podem reduzir os esforços e os custos necessários para viabilização das ações intentadas. 
Outra semelhança entre essas experiências é a busca do mercado externo e a conquista de novos mercados. Vê-se nesse aspecto a clareza de que não basta atuar apenas pelo lado da oferta, mas deve-se atuar também sobre a demanda interna, quando o poder de compra da população permite, e externa, quando o ambiente macroeconômico doméstico é recessivo e o poder de compra da população é exíguo.

Apesar dessas similaridades (tempo de maturação e busca de novos mercados), algumas das experiências citadas distanciam-se quando se pensa em termos da expansão dos benefícios gerados para a população local, e em termos da lógica que conduziu a ação dos atores.

Em Simplício Mendes, por exemplo, o resultado em termos de benefícios pessoais e de valorização do fator trabalho, da cidadania, da participação e dos lucros é mais significativo que no caso de Votuporanga.

Para a experiência do Banco Palmas ser analisada sob o aspecto do desenvolvimento econômico local, é necessária uma mudança de paradigma. Ainda que também se valha de uma forte organização surgida a partir de mobilizações populares, as relações sociais presentes na iniciativa desse bairro de Fortaleza representam novas dinâmicas que podem escapar da nossa percepção. O desenvolvimento econômico aqui deve ser pensado como uma forma de melhorar substancialmente as condições de vida das pessoas da comunidade, levando-as a mínimos sociais que não são providos pelas políticas públicas tradicionais. É uma experiência que se distancia das outras, mesmo as de iniciativa empresarial, por colocar-se de costas para o estado, nesse caso insuficientemente ativo para os setores excluídos. Assim, parece correto pensar que essa experiência de desenvolvimento local também adota imperativos não econômicos, além de propor um desenvolvimento capaz de produzir transformação social a partir da base, "de baixo para cima" (Santos e Rodríguez-Garavito, 2006). As mudanças econômicas são vistas como importantes, mas também são expressão e estratégia para o surgimento de novas práticas sociais mais solidárias. Nesse sentido, o Banco Palmas aproxima-se do ocorrido em Simplício Mendes.

A expansão de ideias, como as desenvolvidas pelas experiências aqui estudadas, encontra-se em pleno vapor no Brasil. Existe um espaço para experimentação e emergência de novas formas de articulações entre os vários atores sociais e o âmbito local privilegia iniciativas dessa natureza, que não reproduzem apenas formas de produção capitalista e também não estão centradas em empreendimentos controlados pelo Estado. São, em geral, formas de organização socioeconômicas baseadas em ações coletivas de empreendimentos populares de gestão solidária (Singer, 2000).

Este tipo de motivação, entretanto, não parece ser monopólio de iniciativas vinculadas a partir de movimentos sociais organizados. No caso da incuba- 
dora tecnológica do setor coureiro-calçadista do estado do Rio Grande do Sul, é o governo estadual quem procura construir novos padrões de relacionamento social a partir da alteração da estrutura produtiva, por meio da articulação de dois instrumentos: incubação de iniciativas econômicas e cooperativismo.

Aqui, parece claro que a sociedade civil tem vantagens na condução de processos com esse tipo de objetivo, por conta das temporalidades conflitantes entre a dinâmica dos governos (submetidos, pelo sistema político, às pressões eleitorais) e a lógica da mudança de mentalidades, dentro e fora do estado.

Essa relativa vantagem da sociedade civil não é universal. Alguns dos casos demonstram que governos podem assumir papel de liderança em processos de promoção do desenvolvimento econômico local. O caso do polo moveleiro do Rio Grande do Sul evidencia um dos papéis possíveis: o de articular relacionamentos em setores nos quais não se verifica capacidade institucional para construir relações de colaboração e confiança.

$\mathrm{O}$ caso da região do $\mathrm{ABC}$, com o Consórcio Intermunicipal e a Câmara do $\mathrm{ABC}$, aponta outra responsabilidade de liderança do governo local: mobilizar os diversos atores locais para promover transformações econômicas que transcendem um ou poucos setores. Nesse caso, com a presença do prefeito de Santo André, Celso Daniel, como um "empreendedor político", ${ }^{8}$ o nível de complexidade era tal que foi necessário constituir uma nova institucionalidade que representasse o novo ator coletivo emergente (Caldas, 2008). Esse ator conseguiu reunir força política suficiente para forçar o governo estadual a integrar-se ao processo. Por conta da aceitação de uma inserção subordinada do Brasil no contexto internacional, o governo do estado de São Paulo, até então, assumira postura de acatar mansamente o processo de perda de dinamismo econômico da região, expresso na sua desindustrialização.

Experiências de iniciativa governamental também são capazes de promover articulações de fôlego, capazes de sobreviver à mudança de natureza eleitoral. Os dois consórcios estudados exemplificam isso. A cooperação entre os municípios instituída pelo Consórcio do Grande $A B C$ mostrou-se uma alternativa viável para executar as tarefas que extrapolam a competência municipal e, também, para racionalizar o uso dos recursos e para obter financiamentos.

A articulação intermunicipal e a criação de uma nova arquitetura institucional - consórcio, câmara, agência - redundaram também no fortalecimento político dos municípios envolvidos. Mais fortes, eles passaram a negociar melhor com o estado e o governo federal, em favor das aspirações e interesses da região.

\footnotetext{
${ }^{8}$ Termo utilizado por Kingdon (2003).
} 
A atuação do consórcio teve como base de atuação o desafio de transformar o modo tradicional de fazer política no nível local, bem como na interlocução responsável com as demais esferas de governo e agentes sociais. Essa condução firme do consórcio buscou reforçar a ideia de uma região proativa, contrapondo-se ao bairrismo, à visão do cenário local como feudo político pessoal, e à tradicional troca de favores no campo intergovernamental. Tendo essa base de sustentação, o consórcio definiu como campo de atuação um amplo leque de questões, abrangendo desde o gerenciamento ambiental até o desenvolvimento regional, estando aberto ao encaminhamento de qualquer tema relativo ao interesse comum dos municípios envolvidos.

Se a experiência do Grande $\mathrm{ABC}$ aponta a possibilidade de constituição de um consórcio com uma pauta ampla de atuação no campo do desenvolvimento, o Cinpra, formado por municípios do Maranhão, liderados por São Luís, tratou-se, na verdade, da solução de um dilema de ação coletiva, no qual o "benefício coletivo" percebido tanto pelos dirigentes municipais, quanto pelos técnicos, produtores, comerciantes e consumidores não desencadeia uma "ação coletiva" desses diversos atores sociais e políticos envolvidos com a produção, deslocamento, estocagem, venda e compra de alimentos. O Cinpra surgiu como um arranjo institucional de cooperação entre municípios para resolução de um problema de abastecimento regional, que logo se tornou um espaço de atuação política conjunta e de resistência às práticas oligárquicas do governo do estado do Maranhão (Caldas, 2008).

Certamente os atores estatais têm papel relevante na promoção do desenvolvimento econômico local, mas isso não significa que sua ação solitária seja suficiente. O caso dos minidistritos industriais de São José do Rio Preto, ainda que sugira que a articulação entre políticas de gestão territorial e políticas de desenvolvimento econômico (e seus distintos responsáveis no interior da administração municipal) seja possível e desejável, desvenda a fragilidade de iniciativas unilaterais. A promoção de um novo padrão de ocupação do território, descolada de iniciativas mais densas de articulação de atores sociais e agentes econômicos, não produziu resultados significativos do ponto de vista da transformação das estruturas produtivas.

Utilizando como parâmetro o conteúdo do projeto político subjacente às experiências, pode-se dizer que a experiência do Polo Moveleiro de Votuporanga, bem-sucedida em seus resultados (geração de negócios), reproduz em escala menor, localizada, a lógica do capital. Em sentido oposto, as experiências de Simplício Mendes e do Banco Palmas introduzem novos valores nas relações sociais, permitindo uma melhor partilha de poder e resultados, além de mostrar-se sustentável em termos de mercado e do ponto de vista ambiental. 
Outras experiências apresentam-se paradoxais: buscam introjetar novos valores, entretanto, essa busca parte do poder estatal que opera em um tempo eleitoral de curto prazo, o que não possibilita a efetivação de seu propósito valorativo (introjeção de valores solidários e cooperativos).

A introjeção de valores solidários e cooperativos é um processo que, como visto, opera uma lógica de prazos longos e demanda uma concepção participativa permeando toda a trajetória da iniciativa. Além disso, nesse processo há necessidade de negociação e articulação com setores cujas expectativas concentram-se em prazos mais curtos. O quadro 2 mostra o repertório de instrumentos analisados para gestão do desenvolvimento local.

\section{Quadro 2}

\section{Atores e instrumentos para gestão social do território}

\begin{tabular}{|c|c|c|}
\hline Experiência & Instrumentos & Atores \\
\hline Polo Moveleiro de Votuporanga & $\begin{array}{l}\text { Formação, centro tecnológico, } \\
\text { indução de ação coletiva }\end{array}$ & $\begin{array}{l}\text { Empresários locais do setor } \\
\text { moveleiro }\end{array}$ \\
\hline $\begin{array}{l}\text { Polo Moveleiro do Estado do Rio } \\
\text { Grande do Sul }\end{array}$ & $\begin{array}{l}\text { Associativismo, fortalecimento } \\
\text { institucional, indução de ação } \\
\text { coletiva, arranjo produtivo local } \\
\text { (APLs) }\end{array}$ & $\begin{array}{l}\text { Governo do Estado do Rio } \\
\text { Grande do Sul, empresários do } \\
\text { setor moveleiro gaúcho }\end{array}$ \\
\hline $\begin{array}{l}\text { Incubadora tecnológica do setor } \\
\text { coureiro-calçadista do estado do } \\
\text { Rio Grande do Sul }\end{array}$ & $\begin{array}{l}\text { Incubadora tecnológica, } \\
\text { formação e capacitação } \\
\text { técnica, clusters }\end{array}$ & $\begin{array}{l}\text { Pequenas e médias empresas do } \\
\text { setor coureiro-calçadista gaúcho, } \\
\text { ONGs, governos locais, sindicatos } \\
\text { de trabalhadores }\end{array}$ \\
\hline $\begin{array}{l}\text { Cooperativa dos Citricultores } \\
\text { Ecológicos do Vale do Caí }\end{array}$ & $\begin{array}{l}\text { Cooperativismo, formação e } \\
\text { capacitação técnica, economia } \\
\text { solidária, agroecologia }\end{array}$ & $\begin{array}{l}\text { Cooperativa, agricultores } \\
\text { familiares, pequenos produtores, } \\
\text { cooperação internacional, ONGs, } \\
\text { movimentos sociais }\end{array}$ \\
\hline Apicultura em Simplício Mendes & $\begin{array}{l}\text { Associativismo, comércio justo } \\
\text { e solidário }\end{array}$ & $\begin{array}{l}\text { Igreja Católica, pequenos } \\
\text { apicultores, Governo do Estado do } \\
\text { Piauí, Sebrae }\end{array}$ \\
\hline $\begin{array}{l}\text { Minidistritos industriais e de } \\
\text { serviços de São José do Rio Preto }\end{array}$ & $\begin{array}{l}\text { Planejamento territorial, } \\
\text { geração de emprego e renda }\end{array}$ & Governo municipal \\
\hline Banco Palmas, Fortaleza & $\begin{array}{l}\text { Economia solidária, } \\
\text { microfinanças, moeda social }\end{array}$ & Associação de moradores \\
\hline $\begin{array}{l}\text { Consórcio Intermunicipal de } \\
\text { Produção e Abastecimento } \\
\text { - Cinpra }\end{array}$ & $\begin{array}{l}\text { Cooperação intermuncipal, } \\
\text { consórcios intermunicipais }\end{array}$ & $\begin{array}{l}\text { Colegiado de prefeitos, governos } \\
\text { municipais, Emater }\end{array}$ \\
\hline $\begin{array}{l}\text { Consórcio Intermunicipal do } \\
\text { Grande ABC }\end{array}$ & $\begin{array}{l}\text { Cooperação intermunicipal, } \\
\text { Agência de Desenvolvimento } \\
\text { Regional (ADR) }\end{array}$ & $\begin{array}{l}\text { Colegiado de prefeitos, governos } \\
\text { municipais, setor privado }\end{array}$ \\
\hline
\end{tabular}




\section{Conclusão}

As experiências estudadas - seus sucessos e fracassos - são ricas em elementos que podem iluminar reflexões sobre as possibilidades e os limites em institucionalizar práticas de desenvolvimento econômico local no Brasil. Tal esforço encontra-se para além do objetivo deste artigo, mas alguns temas centrais podem ser levantados, sob um enfoque de proposição de questões para a continuidade da pesquisa do que de fixação de conclusões.

Primeiramente, é necessário melhor entendimento das possibilidades de articulação dos diferentes instrumentos de promoção do desenvolvimento econômico local. Coerentemente com o paradigma do experimentalismo difuso e com a forma como essas experiências se materializaram nos governos locais brasileiros no período pós-redemocratização, grande parte delas padece de visões fragmentadas, selecionando um ou poucos instrumentos e deixando de explorar complementaridades que poderiam significar novas possibilidades de ação.

Essa articulação dos instrumentos de promoção do desenvolvimento econômico local não pode ocorrer de maneira descontextualizada, evidentemente. Os instrumentos de desenvolvimento econômico local não são universais e, portanto, não podem ser simplesmente replicados em qualquer contexto. Devem ser entendidos como parte do repertório à disposição dos atores, que se valem deles de acordo com o contexto em que se encontram, com seus objetivos e estratégias, na disputa por conteúdos, meios e resultados dos processos de desenvolvimento local e, por fim, de acordo com seus acúmulos e capacidades.

Por conta disso, um segundo ponto precisa ser reforçado: é preciso compreender os distintos papéis dos vários atores sociais, tanto aqueles embasados no território, quanto os de instituições externas à comunidade. Certamente, cada caso apresenta capacidades de intervenção distintas. De que maneira essas capacidades emergem?

O estudo dos casos sugere alguns fatores comuns nas experiências que apontam para alguns padrões de comportamento. Surgem, então, questões como: será possível identificar diversas lógicas presentes numa dada intervenção (capital, trabalho, instituições, política, entre outras)? Como estratégias participativas podem possibilitar a explicitação, a mediação e a resolução dos conflitos decorrentes da confluência dessas lógicas distintas, do ponto de vista do combate à desigualdade e do fortalecimento da democracia?

A compreensão das dinâmicas locais demanda um contraponto: contextualizar o local e relacioná-lo com outras instâncias, a regional, a nacional e a internacional. Do contrário, cair-se-á na armadilha de certo "localismo" ingênuo e pouco efetivo, tomar-se-á a participação em si como elemento de 
suficiência das iniciativas, despregando-as de seu objetivo de transformação efetiva das condições materiais de vida das comunidades.

Buscar compreender essas articulações complexas não é trabalho trivial. Em princípio, podem ser identificados dois níveis de articulação:

v articulação dos instrumentos entre si, levando à necessidade de uma visão intersetorial e integradora nas políticas públicas de desenvolvimento local, com consequente demanda por novos padrões de governança;

v articulação dos atores sociais entre si, envolvendo os processos políticos e sociais que coexistem e determinam o conteúdo das políticas e iniciativas de desenvolvimento local.

A ignorância ou a má interpretação dessa complexidade elevada pode levar a dois tipos de problema na formulação de políticas públicas: a imobilidade ou a busca de fórmulas prontas. No primeiro caso, o risco é deixar-se aprisionar no dilema da ordem de causalidade: como não se consegue ter certeza sobre o que vem antes, a definição e articulação dos instrumentos ou a articulação dos atores, não se faz nem uma nem outra. No segundo caso, acontece o inverso: a partir de uma visão simplista e mecanicista, ou pragmática, da realidade, elege-se um tipo de articulação como fator impulsionador e se atribui a ela toda a responsabilidade pelo sucesso no desenvolvimento local.

Partidários das ideias baseadas em uma noção ligeira de capital social tenderiam a defender a primazia da articulação entre os atores; defensores de uma intervenção focalizada em resultados de prazo mais curto tenderiam a selecionar um conjunto articulado de instrumentos e defender que deva ser construída a articulação de atores que permita sua implantação.

Parece evidente que é necessário levantar uma terceira forma de encarar essa complexidade, que é a da articulação simultânea entre instrumentos e atores, na forma de estratégias situacionais de desenvolvimento local, absolutamente singular no tempo e no espaço, ressaltando o caráter multidimensional e multiescalar desses processos.

Voltando a atenção para outra questão, é preciso deixar claro que existe um sentido político subjacente às escolhas feitas pelos atores. Identificar esse sentido é fundamental não só para compreender os processos, mas também seus impactos futuros. As possibilidades locais de experimentar e refletir sobre o desenvolvimento local desdobram-se normalmente em duas frentes: uma de reprodução da lógica capitalista global em escala localizada e outra de experimentações contra-hegemônicas. 
O local como espaço e território que reproduzem a lógica do capital caracteriza-se, segundo Santos e Rodríguez-Garavito (2006), pela produção, ainda que em escala mais reduzida, de desigualdade de recursos e poder, de formas de sociabilidade empobrecidas produzidas pela concorrência e pelo estímulo individual advindo da cobiça e do medo; e, finalmente, pela exploração crescente dos recursos naturais.

Por outro lado, o local como espaço e território permeável à produção de experiências de resistência e/ou contra-hegemônicas caracteriza-se por produzir espaços nos quais predominam os princípios da igualdade, solidariedade e respeito à natureza.

Ao escolherem essa segunda lógica, as experiências correm o risco de ser cooptadas pela lógica reprodutora de eventuais parceiros e colaboradores e de passarem a operar na lógica do mercado, quando da necessidade de ganharem escala ou mesmo de se articularem com outras instâncias (regionais, estaduais e internacional). As duas perspectivas apresentadas são, sem dúvida, dois extremos de um "contínuo" repleto de possibilidades intermediárias, que permite organizar as experiências e analisá-las.

Para dar conta dessas questões, tem-se o desafio de encarar o local como campo de possibilidades e de experimentações. Assim, a avaliação das experiências deve contemplar certa condescendência com resultados econômicos de curto prazo e buscar olhar para os processos de mais longa duração. Isso exige uma postura de avaliação distinta do mainstream, que possibilite fugir da armadilha das avaliações que escondem a miopia de sua compreensão da realidade, muitas vezes atrás de um fetiche por indicadores e resultados quantificáveis, tão a gosto de certas visões simplificadoras das ciências sociais, que levam crescentemente à despolitização das políticas públicas.

A busca de caminhos para a solução dessas questões, do ponto de vista da investigação, exige uma abertura para análise e avaliação de resultados que descarta modelos preconcebidos ou a eleição de best practices. Por conta disso, observar uma diversidade de experiências é fundamental. Entretanto, ao olhar essa diversidade é preciso identificar questões que emergem de seu conjunto e orientá-las para uma reflexão que possa subsidiar a intervenção dos atores da sociedade civil e dos governos na formulação de propostas e iniciativas de desenvolvimento econômico local.

Do ponto de vista científico, essas questões são válidas e justificam esforços adicionais. Mas a responsabilidade dos pesquisadores exige o alerta de que também sejam consideradas na formulação de políticas públicas. Ser ignoradas pelos estudiosos é grave, mas desprezadas pelos formuladores de 
políticas pode significar a valorização de práticas que se apropriam das ideias e dos compromissos de promoção da cidadania, da igualdade e da democracia para reproduzir e agravar as lógicas de exclusão social e de desigualdade presentes no território.

\section{Referências}

ALTENBURG, T.; MEYER-STAMER, J. How to promote clusters: policy experiences from Latin America. World Development, v. 27, n. 9, p. 1693-1713, 1999.

ALVES, M. M. A força do povo: democracia participativa em Lages. São Paulo: Brasiliense, 1980.

AVRITZER, L. Participatory institutions in democratic Brazil. Johns Hopkins University Press, 2009.

; NAVARRO, Z. A inovação democrática no Brasil. São Paulo: Cortez, 2008.

BACATTINI, G. O distrito marshalliano: uma noção socioeconômica. In: BENKO, G.; LIPIETZ, A. (Orgs.). As regiões ganhadoras. Distritos e redes: os novos paradigmas da geografia econômica. Portugal: Celta, 1994.

BAIOCCHI, G. Militants and citizens: the politics of participation in Porto Alegre. Stanford: University Press, 2005.

BENKO, G.; LIPIETZ, A. O novo debate regional: posições em confronto. In:

(Orgs.). As regiões ganhadoras. Distritos e redes: os novos paradigmas da geografia econômica. Portugal: Celta, 1994.

BOISIER, S. Em busca do esquivo desenvolvimento regional: entre a caixa preta e o projeto político. Revista Planejamento e Políticas Públicas, n. 13, p. 111-143, 1996.

BOURDIEU, P. Le capital social. Actes de La Recherche 3, 1980.

. The forms of capital. In: RICHARDSON, J. (Ed.). The handbook of theory and research for the sociology of education. New York: Geernwood, 1985.

CABANNES, Y. Participatory budgeting: a significant contribution to participatory democracy. Environment and Urbanization, v. 16, n. 1, p. 27-46, 2004.

CALDAS, E. L. Formação de agendas governamentais locais: o caso dos consórcios intermunicipais. 2008. Tese (Doutorado em Ciência Política) — Faculdade de Filosofia, Letras e Ciências Humanas, Universidade de São Paulo, São Paulo. 
COLEMAN, J. The foundations of social theory. Cambridge: Harvard University Press, 1990.

FRANÇA, C. L.; CALDAS, E. L.; VAZ, J. C. Aspectos econômicos de experiências em desenvolvimento local: um olhar sobre a articulação de atores. São Paulo: Instituto Pólis, 2004.

INSTITUTO BRASILEIRO DE GEOGRAFIA E ESTATÍSTICA (IBGE). Malha municipal digital do Brasil: situação em 2001. Rio de Janeiro: IBGE, 2005.

KINGDON, J. W. Agendas, alternatives, and public policies. 2. ed. New York: Longman Classic in Political Science, 2003.

MALUF, R. S. Atribuindo sentido(s) à noção de desenvolvimento. Estudos Sociedade e Agricultura, n. 15, p. 53-86, 2000.

MARQUETTI, A.; CAMPOS, G. A.; PIRES, R. (Orgs.). Democracia participativa e redistribuição: análise de experiências de orçamento participativo. São Paulo: Xamã, 2008.

MARTINS, R. D. A.; CALDAS, E. L. Uma análise comparada de experiências de desenvolvimento econômico local no Brasil. Revista Brasileira de Gestão e Desenvolvimento Regional, v. 5, n. 3, p. 70-93, 2009a.

. Visões do desenvolvimento local: uma análise comparada de experiências brasileiras. Interações, v. 10, n. 2, p. 207-218, 2009 b.

; VAZ, J. C. Participación ciudadana, articulación de actores y desarrollo local: un análisis comparado de experiencias brasileras. Revista Mercatec, v. 43, p. 29-41, 2007.

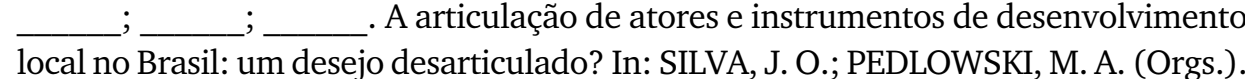
Atores sociais, participação e ambiente. 1. ed. Porto Alegre: Imed/Dacasa, 2008.

MELO, M. A. Crise federativa, guerra fiscal e "hobbesianismo" municipal: efeitos perversos da descentralização? São Paulo em Perspectiva, v. 10, n. 3, p. 11-20, 1996.

MEYER-STAMER, J. Estratégias de desenvolvimento local e regional: clusters, política de localização e competitividade sistêmica. Policy Paper 28. São Paulo: Friedrich Ebert Stiftung, 2001.

OLIVEIRA, F. de. Aproximações ao enigma: o que quer dizer desenvolvimento local? São Paulo: Instituto Pólis, PGPC/FGV-Eaesp, 2001.

OLSON, M. A lógica da ação coletiva: os benefícios públicos e uma teoria dos grupos sociais. São Paulo: Edusp, 1999. 
PUTNAM, R. Comunidade e democracia: a experiência da Itália moderna. Rio de Janeiro: FGV, 1996.

SANTOS, B. de S.; RODRÍGUEZ-GARAVITO, C. A. Introduction: expanding the economic canon and searching for alternatives to neoliberal globalization. In: SANTOS, B. de S. (Org.). Another production is possible. Beyond the capitalist canon. London: Verso, 2006.

SILVA, I. P.; FRANÇA, C. L.; VAZ, J. C. (Orgs.). Aspectos econômicos de experiências em desenvolvimento local. São Paulo: Instituto Pólis, 2002.

SILVEIRA, C.; BOCAYUVA, C.; ZAPATA, T. Ações integradas e desenvolvimento local: tendências, oportunidades e caminhos. São Paulo: Instituto Pólis, PGPC/Eaesp/ FGV, 2001.

SINGER, P. I. O Brasil no limiar do terceiro milênio. Estudos Avançados, v. 14, n. 38, p. 247-259, 2000.

VAZ, J. C.; CALDAS, E. L. Desenvolvimento local e políticas territoriais. In: ENCONTRO NACIONAL DE ADMINISTRAÇÃO PÚBLICA E GOVERNANÇA (EnAPG), 2. Anais... São Paulo, 2006.

WAMPLER, B.; AVRITZER, L. The spread of participatory budgeting in Brazil: from radical democracy to participatory good government. Journal of Latin American Urban Studies, v. 7, p. 37-52, 2005. 